\title{
Relationship of suicide rates to economic variables in Europe: 2000-2011
}

Konstantinos N. Fountoulakis, Wolfram Kawohl, Pavlos N. Theodorakis, Ad J. F. M. Kerkhof, Alvydas Navickas, Cyril Höschl, Dusica Lecic-Tosevski, Eliot Sorel, Elmars Rancans, Eva Palova, Georg Juckel, Goran Isacsson, Helena Korosec Jagodic, Ileana Botezat-Antonescu, Ingeborg Warnke, Janusz Rybakowski, Jean Michel Azorin, John Cookson, John Waddington, Peter Pregelj, Koen Demyttenaere, Luchezar G. Hranov, Lidija Injac Stevovic, Lucas Pezawas, Marc Adida, Maria Luisa Figuera, Maurizio Pompili, Miro Jakovljević, Monica Vichi, Giulio Perugi, Ole Andreassen, Olivera Vukovic, Paraskevi Mavrogiorgou, Peeter Varnik, Per Bech, Peter Dome, Petr Winkler, Raimo K. R. Salokangas, Tiina From, Vita Danileviciute, Xenia Gonda, Zoltan Rihmer, Jonas Forsman Benhalima, Anne Grady, Anne Katrine Kloster Leadholm, Susan Soendergaard, Carlos Nordt and Juan Lopez-Ibor

\section{Background}

It is unclear whether there is a direct link between economic crises and changes in suicide rates.

\section{Aims}

The Lopez-Ibor Foundation launched an initiative to study the possible impact of the economic crisis on European suicide rates

\section{Method}

Data was gathered and analysed from 29 European countries and included the number of deaths by suicide in men and women, the unemployment rate, the gross domestic product (GDP) per capita, the annual economic growth rate and inflation.

\section{Results}

There was a strong correlation between suicide rates and all economic indices except GPD per capita in men but only a correlation with unemployment in women. However, the increase in suicide rates occurred several months before the economic crisis emerged.

\section{Conclusions}

Overall, this study confirms a general relationship between the economic environment and suicide rates; however, it does not support there being a clear causal relationship between the current economic crisis and an increase in the suicide rate.

\section{Declaration of interest}

None.
In 2008 a global economic crisis affected Europe as well as the rest of the world. The crisis caused problems in the banking sector and downturns in stock markets, bankruptcies, house repossessions and there were rises in unemployment. ${ }^{1}$ There was concern expressed about the effect of austerity on healthcare ${ }^{2-15}$ and the World Health Organization (WHO) published its concerns regarding the impact of the crisis on global health, although at least some points were proven exaggerated and unsupported by data and withdrawn later. ${ }^{16-20}$ Mental health is believed to be at a greater risk of being affected by such a crisis, since people with mental disorders (particularly mood disorders) constitute a particularly vulnerable population. Among all adverse effects, the most striking would be an effect on suicidality. It is widely believed that crises of this kind increase suicides, ${ }^{10,16,21-25}$ and this seems to be the conclusion of studies on the Asian economic crisis of the 1990s, with a particular emphasis on the effect of rising unemployment. ${ }^{26,27}$ Thus, it is supposed that the greatest impact is on men of working age. There are several studies suggesting a similar pattern concerning the impact of the recent economic crisis in European countries ${ }^{8,10,28-37}$ and the USA $^{34}$ although different interpretations also exist. ${ }^{19,20,38,39}$ An important limitation of most of these studies on European rates is that they analyse the suicide rates from 2007 on and not before, although they do report a nadir for suicide rates during 2007, and they focus almost exclusively on the possible effect of unemployment, thus neglecting other factors.

The Lopez-Ibor Foundation launched an initiative to study the possible impact of the economic crisis on European suicide rates. A group of experts were gathered from participating countries and data concerning suicide rates since 2000, along with economic indices, were gathered and analysed. The hypothesis was that suicide rates correlate with unemployment, growth rate and inflation, which are aspects of the economic situation that have a direct impact on the everyday life of the population and especially of vulnerable groups.

\section{Method}

\section{Data acquisition}

Data were gathered from 29 European countries (see online Table DS1). The data included number of men and women in the population, number of deaths by suicide in men and women, unemployment rate, gross domestic product (GDP) per capita, annual economic growth rate and inflation. All data were collected strictly from the official national statistical agencies of countries. The economic variables used were defined according to the World Bank definitions. Some discrepancies between the data obtained from national agencies and those of Eurostat were detected (for example Poland). The data from the national agencies were used in all instances.

The suicide rates were calculated as number of suicides per 100000 inhabitants without adjusting for age, since European countries do not differ significantly in terms of age composition of their populations. Adjusting for age and gender on the basis of a standardised population was not feasible since data of this kind were not readily available for all countries and all years.

The unemployment rate refers to the share of the labour force that is without work but available for and seeking employment. 
Definitions of labour force and unemployment differ by country, but among European countries differences are not large. Typically, the total labour force comprises people ages 15 and older who meet the International Labour Organization definition of the economically active population: all people who supply labour for the production of goods and services during a specified period. It includes both the employed and the unemployed. Although national practices vary in the treatment of such groups as the armed forces and seasonal or part-time workers, in general the labour force includes the armed forces, the unemployed and first-time job-seekers, but excludes homemakers and other unpaid caregivers and workers in the informal sector.

Gross domestic product is the sum of gross value added by all resident producers in the economy plus any product taxes and minus any subsidies not included in the value of the products. It is calculated without making deductions for depreciation of fabricated assets or for depletion and degradation of natural resources.

The annual GDP growth was defined as the annual percentage growth rate of GDP at market prices based on constant local currency. The GDP per capita was defined as GDP divided by mid-year population.

Inflation, as measured by the consumer price index, reflects the annual percentage change in the cost to the average consumer of acquiring a basket of goods and services that may be fixed or changed at specified intervals, such as yearly. The Laspeyres formula is generally used.

All the raw data are shown in online Table DS1, and online Fig. DS1 shows the total suicide rates for each country.

\section{Data analysis}

Three sets of data were obtained concerning suicides: the total rate and the rates in men and women. The total and the rates in men followed a loglinear distribution whereas the rate in women followed a normal distribution (Fig. 1).

To allow different time trends of suicide rates between countries a random coefficient regression model was applied. Specifically, we used the procedure NLMIXED in SAS 9.3 for Windows with log as link function. The model error term as well as the two random coefficients (country and country $\times$ time) were assumed to be normally distributed. Calendar year was rescaled to be zero in 2000 and GDP per capita was divided by 1000 to enhance estimation of the model as well as interpretation of effects.

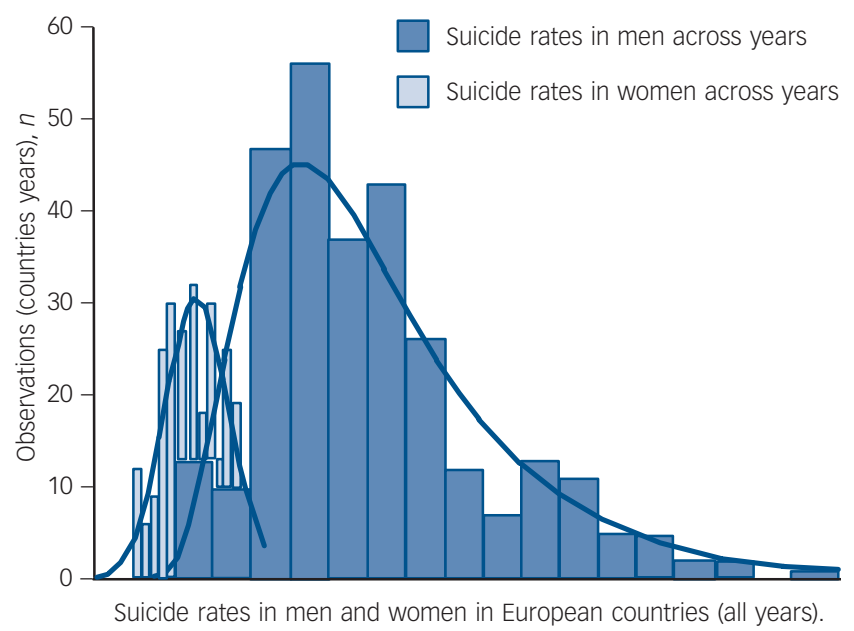

Fig. 1 Histogram of suicide rates: pooled data for all countries and all years.
The dependent variables were total suicide rate and rate in men for the first two and rate in women for the third. Country was used as a categorical predictor and the economic variables (unemployment, growth rate, GDP, GDP per capita and inflation) and year as continuous predictors. We chose to use rates rather than numbers as dependent variables for two reasons. First, the use of rates would put all countries at a similar level and would not give any advantage to the big ones, thus preserving the 'qualitative' differences between countries. Second, the absolute number of suicides did not fit any of the basic distributions and the models derived had poor goodness-of-fit. Countries with more than 1 year of missing data were not included in the models (Bulgaria, Montenegro, Belgium, Italy).

Following the above multifactorial analyses, several exploratory analyses were applied to the data for each country separately using the non-parametric Spearman correlation coefficient. The calculation of the coefficients was done for the total time span (years 2000-2011) and also for two separate periods (2000-2005 and 2006-2011) since it was obvious that after 2006 a change in suicide trends was evident. The correlations between total suicide rates and rates in men and women with the economic variables mentioned above were calculated for each country separately.

Non-parametric Kruskal-Wallis ANOVA was used to test numerical differences between groups.

\section{Results}

The combined data of European countries for the years 2000-2010 are shown in Table 1 and the evolution of suicides in Europe across the years in Fig. 2. Pooled data from only those countries with 2011 data as well and separately for Eurozone, European Union (EU) and the rest of the European countries can be found in online Table DS1. Online Fig. DS1 shows suicide $v$. time for individual countries. Overall the data from the 29 countries show a decreasing trend from year 2000 to 2011 for suicide rates both for men and for women (Table 1, Fig. 2, online Table DS1 and online Fig. DS1).

The results of the regression analyses are shown in Table 2 for total suicide rates and in Table 3 for men and women separately. They suggest that total suicides rates and rates for men were related to all economic variables except GDP per capita. Rates for women were only related to unemployment. As expected, year and country also had a significant effect.

The inspection of data revealed there was a clear increasing trend in Slovakia. In Greece the maximum rate emerged in 2012 and a stabilising trend seems to be in place. Stable rates across the years were observed in the Netherlands, Romania, Norway, Montenegro and Sweden, whereas the rates for Portugal fluctuated greatly. In the other 21 countries the trend was towards lower overall suicide rates for 2010-2011 in comparison with 2000, however only in 4 of these countries (Bulgaria, Estonia, Finland and Switzerland) was this decrease continuous and un-intermittent (online Table DS1 and online Fig. DS1). With the exception of these 4 countries (Bulgaria, Estonia, Finland and Switzerland), for the other 25 countries the rate of suicides reached a nadir during the years 2006-2009 (Table 4, online Table DS1 and online Fig. DS1). In the countries that manifested this nadir, the rates were unstable for the next year; for some a trend to increase was clear (such as the Netherlands), in others the rates increased for 1-2 years only to further decrease afterwards (such as Spain), whereas in others the rates were more or less stable (such as France). In Spain the 2012 data suggest a 10\% decrease, thus further perplexing the picture.

There are no common features, in terms of economy, characterising the four countries with an un-intermittent fall in 
their suicide rates. Estonia experienced significant recession, Bulgaria and Finland experienced recession to a lesser extent and Switzerland only marginal recession. Slovakia, which is the only country with increasing suicide rates, experienced recession only for 1 year and its unemployment and GPD growth rates have been steadily improving since 2000. It is important to note that Slovenia did not experience any recession after 2005, however, it manifested a nadir of suicide rates in 2008 followed by an increase. Nonetheless, in the same country, in spite of significant recession during the years 2000-2005, at that time the suicide rates were dropping. Montenegro is another interesting example. In that country, the suicide rate remained unchanged throughout 2000 2010 , in spite of a high growth rate. In that country the unemployment rate remained high and unchanged as well. Portugal is an exception. It experienced a recession with an increase in the suicide rate in 2003. It is the only country without a clear reduction in the suicide rates during 2000-2011. Its 2011 rate is almost double of that of 2000 .

Although the data are complex, three major patterns could be identified (Fig. 3). Pattern A is followed by 13 countries, pattern B by 3 and pattern C by 11 countries (Table 4, online Fig. DS1). Montenegro and Switzerland did not follow any of these patterns. The comparison of pattern A $v$. pattern $\mathrm{C}$ countries suggested there was a tendency for pattern $\mathrm{C}$ countries to have better economic indices and lower suicide rates but this difference was not significant. There was also no correlation of unemployment rate at the year of nadir suicide rates and the rate of suicide increase afterwards.

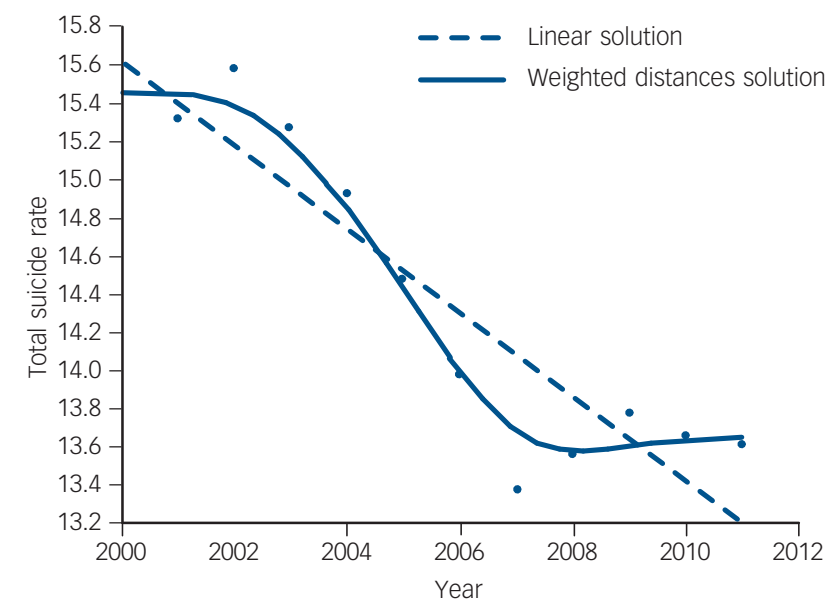

Fig. 2 Change in suicide rates in Europe 2000-2010: pooled data.
From the above it is evident that the great majority of countries manifested a halt in their decreasing suicide rates with a nadir in rates during the years 2006-2008, followed by an increase, which in half of them was temporary. The temporal relationship of this nadir in the decreasing rates to the onset of recession for each country is shown in Table 4. Onset of recession could be defined here as either a negative sign of growth rate or an increase in unemployment (see online Table DS1). The duration of this recession for each country is also shown in Table 4. In 23 countries the nadir in suicides occurred clearly before and in only 2 it occurred after the recession had started.

The mean occurrence of nadir was early 2007 whereas the mean onset of recession was mid-2008. The average latency time from suicide nadir to recession onset was 1.44 years (17.3 months, s.d. $=0.82$ years $).$ The average latency time to recession according to GDP was 1.44 years ( 17.3 months, s.d. $=0.84$ years $)$ and to recession according to the unemployment increase was 1.72 years (20.6 months, s.d. $=0.98$ years). There were no differences between rates in men and women for this issue. All latency times were greater than 1 year, suggesting that clearly the change in slope of the suicide line occurred some months before the respected change in the slope of economic indices.

The Spearman correlation coefficients separately for each country, for total suicide rates and rates for men and women and economic indices, are shown in Table 5. The coefficients are also shown in online Table DS1 together with the coefficients calculated separately for the years 2000-2005 and 2006-2011. The coefficients with values over 0.5 (arbitrary chosen) are shown in Table 4. Some countries kept the same coefficients in this subanalysis but others did not. This sub-analysis should be considered to be purely exploratory.

The correlation coefficient results suggest that the suicide rates are strongly correlated with GDP per capita and its changes and to a lesser extent with unemployment, which is in sharp contrast to the regression analysis results. Some countries (Greece, Spain, Portugal, Montenegro, Norway and Serbia) show very weak correlations of the suicide rates with economic indices.

In Table 6 the correlation coefficients between suicide rates and economic variables across countries for the same year are shown. Overall correlations are weak, with GDP per capita and unemployment showing some stronger tendencies.

\section{Discussion}

\section{Main findings}

Suicide rates have increased dramatically over the past 45 years despite prevention efforts. ${ }^{40}$ There is marked geographic variability

\begin{tabular}{|c|c|c|c|c|c|c|c|c|c|}
\hline \multirow[b]{2}{*}{ Year } & \multicolumn{3}{|c|}{ Population } & \multicolumn{3}{|c|}{ Suicides, $n$} & \multicolumn{3}{|c|}{ Suicide rate } \\
\hline & Total & Men & Women & Total & Men & Women & Total & Men & Women \\
\hline 2000 & 430147247 & 209459316 & 220669932 & 59873 & 45153 & 14720 & 13.92 & 21.56 & 6.67 \\
\hline 2001 & 431483804 & 210282349 & 221201455 & 58624 & 44520 & 14104 & 13.59 & 21.17 & 6.38 \\
\hline 2002 & 432729703 & 210978947 & 221750756 & 59592 & 45072 & 14520 & 13.77 & 21.36 & 6.55 \\
\hline 2003 & 434540344 & 211934885 & 222605459 & 58583 & 44478 & 14105 & 13.48 & 20.99 & 6.34 \\
\hline 2004 & 435941409 & 212670297 & 223271112 & 57963 & 43821 & 14122 & 13.30 & 20.61 & 6.33 \\
\hline 2005 & 437969462 & 213759938 & 224209524 & 56325 & 42515 & 13810 & 12.86 & 19.89 & 6.16 \\
\hline 2006 & 439537845 & 214600383 & 224936462 & 53895 & 40872 & 13011 & 12.26 & 19.05 & 5.78 \\
\hline 2007 & 441202320 & 215434814 & 225687506 & 51615 & 39140 & 12485 & 11.70 & 18.17 & 5.53 \\
\hline 2008 & 443251055 & 216648416 & 226603639 & 53376 & 40684 & 12692 & 12.04 & 18.78 & 5.60 \\
\hline 2009 & 444825169 & 217452639 & 227373530 & 54437 & 42154 & 12012 & 12.24 & 19.39 & 5.28 \\
\hline 2010 & 446575604 & 218367743 & 228207924 & 53504 & 41221 & 12283 & 11.98 & 18.88 & 5.38 \\
\hline
\end{tabular}




\begin{tabular}{|c|c|c|c|c|}
\hline Total suicide rates & Estimate & s.e. & $t$-value & $P$ \\
\hline Intercept & 1.8898 & 0.1033 & 18.3 & $<0.0001$ \\
\hline GDP per capita /1000 & -0.00256 & 0.001492 & -1.72 & 0.0921 \\
\hline National unemployment rate & 0.005579 & 0.00106 & 5.26 & $<0.0001$ \\
\hline National growth rate & -0.00401 & 0.000639 & -6.28 & $<0.0001$ \\
\hline Inflation & -0.00327 & 0.001195 & -2.74 & 0.0086 \\
\hline Year - 2000 & -0.0189 & 0.00363 & -5.21 & $<0.0001$ \\
\hline Men & 1.3839 & 0.1171 & 11.82 & $<0.0001$ \\
\hline $\mathrm{D} 11^{\mathrm{b}}$ & 0.3202 & 0.06805 & 4.71 & $<0.0001$ \\
\hline $\mathrm{D} 21^{\mathrm{C}}$ & -0.00871 & 0.002457 & -3.54 & 0.0009 \\
\hline $\mathrm{D} 22^{\mathrm{d}}$ & 0.000408 & 0.000112 & 3.64 & 0.0007 \\
\hline Error & 1.482 & 0.09553 & 15.51 & $<0.0001$ \\
\hline -2 Log-likelihood & 2258.8 & & & \\
\hline \multicolumn{5}{|c|}{$\begin{array}{l}\text { GDP, gross domestic product. } \\
\text { a. With country and country year as random effects. Total suicide rates are related to all economic variables. As expected, year and country also had a significant effect, except for } \\
\text { Romania and Switzerland. } \\
\text { b. D11 is the estimated random variance of the country-specific intercepts. } \\
\text { c. D21 is the covariance of D1 and D2. It is a very common finding in longitudinal regression analysis that there is a negative covariance between intercept and slope. } \\
\text { d. D22 is the estimated random variance of the country-specific time trends. }\end{array}$} \\
\hline
\end{tabular}

\begin{tabular}{|c|c|c|c|c|}
\hline & Estimate & s.e. & $t$-value & $P$ \\
\hline \multicolumn{5}{|l|}{ Rates in men } \\
\hline Intercept & 3.2261 & 0.1167 & 27.64 & $<0.0001$ \\
\hline GDP per capita /1000 & -0.00387 & 0.001876 & -2.06 & 0.0506 \\
\hline National unemployment rate & 0.005096 & 0.001369 & 3.72 & 0.0011 \\
\hline National growth rate & -0.00412 & 0.000831 & -4.96 & $<0.0001$ \\
\hline Inflation & -0.00347 & 0.001527 & -2.27 & 0.0328 \\
\hline Year - 2000 & -0.01405 & 0.004467 & -3.14 & 0.0045 \\
\hline $\mathrm{D} 11^{\mathrm{b}}$ & 0.3096 & 0.08933 & 3.47 & 0.0021 \\
\hline $\mathrm{D} 21^{\mathrm{C}}$ & -0.00852 & 0.002999 & -2.84 & 0.0093 \\
\hline $\mathrm{D} 22^{\mathrm{d}}$ & 0.00035 & 0.000124 & 2.83 & 0.0094 \\
\hline Error & 2.3952 & 0.2185 & 10.96 & $<0.0001$ \\
\hline -2 Log-likelihood & 1293.1 & & & \\
\hline \multicolumn{5}{|l|}{ Rates in women } \\
\hline Intercept & 1.8225 & 0.1265 & 14.41 & $<0.0001$ \\
\hline GDP per capita /1000 & 0.004294 & 0.002657 & 1.62 & 0.1197 \\
\hline National unemployment rate & 0.008235 & 0.002745 & 3 & 0.0064 \\
\hline National growth rate & -0.0024 & 0.001814 & -1.33 & 0.1981 \\
\hline Inflation & 0.000872 & 0.00309 & 0.28 & 0.7804 \\
\hline Year -2000 & -0.03169 & 0.005815 & -5.45 & $<0.0001$ \\
\hline $\mathrm{D} 11^{\mathrm{b}}$ & 0.3209 & 0.09687 & 3.31 & 0.003 \\
\hline $\mathrm{D} 21^{\mathrm{C}}$ & -0.00695 & 0.003761 & -1.85 & 0.0775 \\
\hline $\mathrm{D} 22^{\mathrm{d}}$ & 0.000448 & 0.000171 & 2.62 & 0.0154 \\
\hline Error & 0.5432 & 0.04908 & 11.07 & $<0.0001$ \\
\hline -2 Log-likelihood & 829.6 & & & \\
\hline \multicolumn{5}{|c|}{$\begin{array}{l}\text { GDP, gross domestic product. } \\
\text { a. With country and country year as random effects. Rates in men are related to all economic variables. Rates in women are not related to the national growth rate. As expected } \\
\text { year and country also had a significant effect except for Poland for rates in men. } \\
\text { b. D11 is the estimated random variance of the country-specific intercepts. } \\
\text { c. D21 is the covariance of D1 and D2. It is a very common finding in longitudinal regression analysis that there is a negative covariance between intercept and slope. } \\
\text { d. D22 is the estimated random variance of the country-specific time trends. }\end{array}$} \\
\hline
\end{tabular}

in suicide rates, with the highest rates being found in Eastern Europe and some US states and the lowest in Muslim and Latin American countries. ${ }^{40,41}$ So far, this variability in suicide rates has not been satisfactorily explained. This variability is particularly true for the continent of Europe. Reasons for these great differences between national/regional suicide rates have not been fully explained yet. Geographic (latitude, longitude, altitude) climatic, dietary, genetic, economic, religious and other sociocultural differences can be taken into account. However, differences in psychiatric morbidity, the accuracy of the registration of suicide, the stigma associated with mental illness and suicide (possibly influencing help-seeking behaviour and reporting rates), the availability of lethal methods, and the availability of the social and healthcare systems should be considered. ${ }^{40,42}$

The current study analysed the correlation between suicide rates in 29 European countries and economic indices. Although a correlation is evident, the temporal relationships do not support a direct link between the economic crisis and any change in the suicide rates. It also found the following results.

(a) There was a nadir for suicide rates across Europe around the year 2007. This synchronisation cannot be considered to be random; instead some common aetiology should have influenced the rates across the continent. 
Table 4 Year of nadir in suicide rates and onset of recession according to two indices (growth rate and unemployment and duration of recession according to each one) as well as pattern of suicide rates evolution and correlations between suicide rates and economic indices in European countries

\begin{tabular}{|c|c|c|c|c|c|c|c|c|c|c|c|c|}
\hline & \multicolumn{3}{|c|}{$\begin{array}{l}\text { Year of suicide } \\
\text { rate nadir }\end{array}$} & \multicolumn{2}{|c|}{$\begin{array}{l}\text { Recession indices, start } \\
\text { year (duration in years) } \\
\end{array}$} & \multicolumn{3}{|c|}{$\begin{array}{l}\text { Timing of nadir } \\
\text { in suicide rates }\end{array}$} & \multicolumn{4}{|c|}{$\begin{array}{l}\text { Correlations between total suicide } \\
\text { rate and economic indices }\end{array}$} \\
\hline & Total & Men & Women & $\begin{array}{l}\text { Growth } \\
\text { rate }\end{array}$ & $\begin{array}{l}\text { Unemploy- } \\
\text { ment }\end{array}$ & Pattern & $\begin{array}{l}\text { Before } \\
\text { recession } \\
\text { started }\end{array}$ & $\begin{array}{l}\text { After } \\
\text { recession } \\
\text { started }\end{array}$ & $\begin{array}{l}\text { National } \\
\text { unemployment } \\
\text { rate }\end{array}$ & $\begin{array}{l}\text { National } \\
\text { growth } \\
\text { rate }\end{array}$ & $\begin{array}{c}\text { GDP } \\
\text { (per } \\
\text { capita) }\end{array}$ & Inflation \\
\hline \multicolumn{13}{|c|}{ Eurozone countries } \\
\hline Austria & 2010 & 2010 & 2010 & $2009(1)$ & 2009 (3) & A & & + & & & -0.90 & \\
\hline Belgium & 2007 & 2007 & 2007 & 2009 (1) & $2009(2)$ & B & + & & & & -0.81 & \\
\hline Estonia & - & - & - & $2008(2)$ & 2009 (3) & $A$ & & & & & -0.90 & \\
\hline Finland & - & - & - & 2009 (1) & $2010(3)$ & $A$ & & & 0.72 & & -0.89 & \\
\hline France & 2007 & 2007 & 2011 & $2008(2)$ & 2009 (3) & A & + & & & & -0.85 & \\
\hline Germany & 2007 & 2007 & 2006 & 2009 (1) & 2011 (1) & C & + & & & & -0.77 & \\
\hline Greece & 2007 & 2007 & 2010 & 2009 (3) & 2009 (3) & $A$ & + & & & & & \\
\hline Italy & 2006 & 2006 & 2006 & $2008(2)$ & $2008(2)$ & $\mathrm{C}$ & + & & 0.86 & & -0.83 & \\
\hline Ireland & 2007 & 2007 & 2006 & 2008 (3) & 2008 (4) & C & + & & -0.56 & & -0.71 & \\
\hline Netherlands & 2007 & 2007 & 2007 & 2009 (1) & 2009 (3) & C & + & & & & & \\
\hline Portugal & 2006 & 2006 & 2006 & $2008(2)$ & 2009 (3) & $\mathrm{C}$ & + & & & & & \\
\hline Slovakia & 2006 & 2006 & 2006 & 2009 (1) & 2009 (2) & C & + & & -0.58 & & 0.73 & -0.58 \\
\hline Slovenia & 2008 & 2008 & 2010 & - & 2009 (3) & C & + & & 0.56 & -0.82 & -0.94 & 0.63 \\
\hline Spain & 2007 & 2007 & 2006 & 2009 (2) & $2008(3)$ & B & + & & & & & \\
\hline \multicolumn{13}{|c|}{$\begin{array}{l}\text { European Union, non- } \\
\text { Eurozone countries }\end{array}$} \\
\hline Bulgaria & 2009 & 2010 & 2009 & 2009 (1) & 2009 (2) & $A$ & & + & & 0.81 & -0.66 & \\
\hline Croatia & 2007 & 2007 & 2009 & 2009 (2) & 2009 (3) & $\mathrm{C}$ & + & & 0.76 & & -0.79 & \\
\hline Czech Rep & 2008 & 2008 & 2007 & 2009 (1) & 2009 (2) & $\mathrm{C}$ & + & & 0.59 & & -0.82 & \\
\hline Denmark & 2007 & 2007 & 2005 & $2008(2)$ & 2009 (3) & $A$ & + & & & & -0.92 & \\
\hline Hungary & 2007 & 2006 & 2010 & 2009 (1) & 2009 (3) & A & + & & -0.79 & 0.63 & -0.87 & 0.52 \\
\hline Latvia & 2007 & 2007 & 2006 & 2008 (3) & $2008(4)$ & $A$ & + & & & & -0.84 & \\
\hline Lithuania & 2007 & 2006 & 2007 & 2009 (1) & 2009 (3) & A & + & & & & -0.86 & -0.78 \\
\hline Poland & 2007 & 2007 & 2007 & - & 2009 (2) & $\mathrm{C}$ & + & & 0.79 & -0.62 & -0.74 & \\
\hline Romania & 2007 & 2007 & 2007 & 2009 (2) & 2009 (3) & $A$ & + & & 0.59 & & -0.63 & 0.57 \\
\hline Sweden & 2007 & 2007 & 2008 & $2008(2)$ & 2009 (3) & B & + & & & & -0.57 & \\
\hline UK & 2007 & 2007 & 2007 & $2008(2)$ & 2009 (2) & $A$ & + & & & & & -0.80 \\
\hline \multicolumn{13}{|c|}{$\begin{array}{l}\text { Non-European union } \\
\text { countries }\end{array}$} \\
\hline Montenegro & - & - & - & - & 2009 (1) & - & & & & & & \\
\hline Norway & 2007 & 2007 & 2006 & 2008 (4) & 2009 (3) & C & + & & & & & \\
\hline Serbia & 2008 & 2008 & 2010 & 2009 (1) & 2009 (3) & A & + & & & & & \\
\hline Switzerland & - & - & - & 2009 (1) & 2009 (2) & - & & & -0.52 & & 0.61 & \\
\hline
\end{tabular}

A

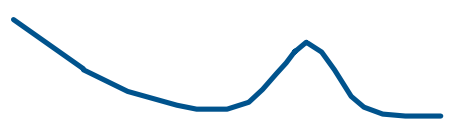

B

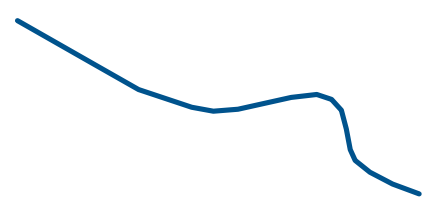

C

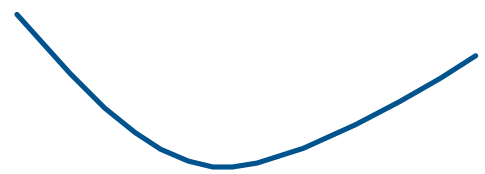

Fig. 3 Patterns of change in suicide data in European countries in relation to the 2007 nadir.

Pattern A: the declining suicide rate is followed by a temporal increase after 2007 and then stabilises; in pattern $\mathrm{B}$ the declining suicide rate is interrupted by a temporal increase after 2007 and then the decline continues; in pattern C the declining suicide rate is reversed after 2007. (b) Even in countries with more or less stable rates, the specific nadir was evident.

(c) The nadir occurred more than a year before the onset of the economic crisis and the subsequent increase in suicide rates also occurred several months before the crisis.

(d) There was a strong correlation of suicide rates with all economic indices except GDP per capita in men but only with unemployment in females. For the vast majority of countries the suicide rates correlated strongly with GDP per capita and rather weakly with unemployment and the other indices. This correlation was strong within each country and less strong across countries.

(e) In Eurozone countries the correlation with GDP per capita was the dominant pattern. In the rest of EU countries the correlation with unemployment was also strong. In countries outside the EU, the correlation of suicide rates with economic variables was weak.

(f) The combined data from European countries for the years 2000-2010 (Table 1 and online Table DS1 and online Fig. DS1) suggest that the average suicide rate in the European region is similar to that reported for the USA. 
Table 5 Correlation coefficients between suicide rates and economic indices for each European country

\begin{tabular}{|c|c|c|c|c|c|c|c|c|c|c|c|c|}
\hline \multirow[b]{2}{*}{ Year } & \multicolumn{4}{|c|}{ Total suicide rate } & \multicolumn{4}{|c|}{ Suicide rate in men } & \multicolumn{4}{|c|}{ Suicide rate in women } \\
\hline & $\begin{array}{l}\text { National } \\
\text { unemploy- } \\
\text { ment rate }\end{array}$ & $\begin{array}{l}\text { National } \\
\text { growth } \\
\text { rate }\end{array}$ & $\begin{array}{l}\text { GDP } \\
\text { (per } \\
\text { capita) }\end{array}$ & Inflation & $\begin{array}{l}\text { National } \\
\text { unemploy- } \\
\text { ment rate }\end{array}$ & $\begin{array}{l}\text { National } \\
\text { growth } \\
\text { rate }\end{array}$ & $\begin{array}{l}\text { GDP } \\
\text { (per } \\
\text { capita) }\end{array}$ & Inflation & $\begin{array}{l}\text { National } \\
\text { unemploy- } \\
\text { ment rate }\end{array}$ & $\begin{array}{l}\text { National } \\
\text { growth } \\
\text { rate }\end{array}$ & $\begin{array}{c}\text { GDP } \\
\text { (per } \\
\text { capita) }\end{array}$ & Inflation \\
\hline \multicolumn{13}{|c|}{ Eurozone countries } \\
\hline Austria & -0.31 & 0.05 & -0.90 & -0.09 & -0.29 & 0.01 & -0.89 & -0.11 & -0.41 & -0.12 & -0.80 & 0.07 \\
\hline Belgium & 0.26 & -0.33 & -0.81 & 0.00 & 0.26 & -0.33 & -0.81 & 0.00 & 0.32 & -0.48 & -0.86 & -0.38 \\
\hline Estonia & 0.17 & 0.11 & -0.90 & -0.22 & 0.19 & 0.01 & -0.87 & -0.27 & 0.03 & 0.24 & -0.85 & -0.05 \\
\hline Finland & 0.72 & -0.08 & -0.89 & 0.07 & 0.68 & -0.05 & -0.86 & 0.10 & 0.77 & 0.00 & -0.90 & -0.16 \\
\hline France & -0.25 & 0.26 & -0.85 & 0.29 & -0.22 & 0.19 & -0.80 & 0.32 & -0.47 & 0.36 & -0.82 & 0.27 \\
\hline Germany & 0.10 & 0.00 & -0.80 & -0.24 & 0.03 & -0.00 & -0.75 & -0.24 & 0.26 & 0.01 & -0.87 & -0.22 \\
\hline Greece & 0.23 & -0.07 & 0.04 & -0.08 & 0.24 & -0.36 & 0.38 & 0.12 & 0.17 & 0.33 & -0.38 & -0.15 \\
\hline Italy & 0.94 & 0.22 & -0.91 & 0.38 & 0.89 & 0.06 & -0.84 & 0.28 & 0.90 & 0.47 & -0.91 & 0.49 \\
\hline Ireland & -0.56 & 0.14 & -0.71 & 0.25 & -0.46 & 0.10 & -0.73 & 0.11 & -0.16 & -0.09 & -0.07 & 0.09 \\
\hline Netherlands & 0.27 & 0.12 & 0.00 & 0.07 & 0.17 & -0.08 & 0.17 & 0.00 & 0.08 & 0.11 & -0.51 & 0.35 \\
\hline Portugal & 0.13 & -0.39 & 0.16 & -0.05 & 0.19 & -0.45 & 0.14 & -0.08 & 0.23 & -0.19 & 0.23 & -0.22 \\
\hline Slovakia & -0.58 & -0.25 & 0.73 & -0.58 & -0.62 & -0.31 & 0.74 & -0.66 & 0.14 & -0.24 & -0.03 & 0.34 \\
\hline Slovenia & 0.56 & -0.82 & -0.94 & 0.63 & 0.60 & -0.83 & -0.90 & 0.58 & 0.39 & -0.73 & -0.85 & 0.59 \\
\hline Spain & 0.06 & 0.34 & -0.41 & 0.12 & 0.14 & 0.25 & -0.35 & 0.04 & -0.17 & 0.48 & -0.31 & 0.55 \\
\hline \multicolumn{13}{|c|}{$\begin{array}{l}\text { European union, } \\
\text { non-Eurozone countries }\end{array}$} \\
\hline Bulgaria & 0.14 & 0.81 & -0.66 & 0.43 & -0.11 & 0.64 & -0.43 & 0.37 & -0.11 & 0.55 & -0.37 & 0.60 \\
\hline Croatia & 0.76 & 0.26 & -0.79 & 0.12 & 0.59 & 0.18 & -0.73 & 0.10 & 0.69 & 0.33 & -0.73 & 0.23 \\
\hline Czech Rep & 0.59 & 0.01 & -0.82 & -0.17 & 0.61 & -0.01 & -0.81 & -0.16 & 0.43 & 0.05 & -0.85 & 0.04 \\
\hline Denmark & -0.36 & 0.26 & -0.94 & 0.01 & -0.10 & 0.11 & -0.91 & 0.14 & -0.59 & 0.44 & -0.65 & 0.17 \\
\hline Hungary & -0.79 & 0.63 & -0.87 & 0.52 & -0.77 & 0.57 & -0.88 & 0.57 & -0.81 & 0.79 & -0.72 & 0.45 \\
\hline Latvia & 0.11 & 0.04 & -0.84 & -0.37 & 0.13 & 0.02 & -0.87 & -0.43 & 0.00 & 0.11 & -0.81 & -0.32 \\
\hline Lithuania & 0.39 & -0.01 & -0.86 & -0.78 & 0.30 & 0.08 & -0.82 & -0.77 & 0.39 & 0.17 & -0.82 & -0.56 \\
\hline Poland & 0.79 & -0.62 & -0.74 & -0.06 & 0.78 & -0.66 & -0.71 & -0.04 & 0.72 & -0.46 & -0.83 & -0.01 \\
\hline Romania & 0.59 & 0.04 & -0.63 & 0.57 & 0.63 & 0.10 & -0.49 & 0.42 & 0.25 & 0.27 & -0.45 & 0.54 \\
\hline Sweden & -0.15 & -0.41 & -0.57 & -0.38 & -0.22 & -0.51 & -0.41 & -0.17 & -0.11 & -0.24 & -0.52 & -0.42 \\
\hline UK & -0.39 & 0.46 & -0.34 & -0.80 & -0.31 & 0.48 & -0.40 & -0.78 & -0.54 & 0.42 & -0.16 & -0.67 \\
\hline \multicolumn{13}{|c|}{ Non-European union countries } \\
\hline Montenegro & 0.25 & 0.11 & -0.07 & 0.36 & 0.61 & 0.18 & -0.18 & 0.18 & -0.07 & -0.47 & -0.33 & 0.53 \\
\hline Norway & 0.17 & 0.17 & -0.26 & 0.22 & 0.03 & -0.03 & -0.42 & 0.39 & 0.02 & 0.04 & 0.54 & -0.23 \\
\hline Serbia & -0.46 & 0.19 & -0.10 & 0.29 & -0.43 & 0.16 & -0.23 & 0.36 & -0.55 & 0.33 & 0.08 & 0.28 \\
\hline Switzerland & -0.52 & -0.04 & 0.61 & 0.23 & -0.51 & 0.09 & 0.56 & 0.37 & -0.51 & 0.03 & 0.64 & 0.31 \\
\hline
\end{tabular}

Several conclusions can be made on the basis of the above. First, these data clearly dispute the assumption that specifically changes in unemployment have a direct effect on suicide rates. The temporal sequence and correlation of events (suicide rise first, economic recession follows, synchronisation of suicide rate changes across the continent) suggests there is a close relationship between the economic environment and suicide rates; however this relationship is not that of a direct cause and effect. The findings reported by the present study concerning Europe are similar to those reported for the USA. In spite of claims that the rise in unemployment caused a rise in the suicide rate in the USA, ${ }^{34}$ a closer look at the data revealed that suicides rose first and unemployment followed. ${ }^{39}$ One could argue that those people who are going to lose their jobs are stressed months before this happens, but 'fear' of unemployment is quite different from unemployment per se, especially since such an assumption suggests that employed people take their own life before they become unemployed.

Second, it is certain that an 'event' occurred in the European continent after 2005 and had a profound effect on suicide rates, probably by halting the ongoing reduction in suicide rates. The strong correlation of these rates with GDP per capita and the weaker but still important correlation with the other economic indices suggest that this event was probably the prodromal phase of the economic crisis. Unfortunately, no data concerning this 'prodrome' can be found in the literature.
It is important however to place a question mark on the nature of the 2007 nadir in the suicide rates. This nadir was evident as a sharp decline from previous year even in countries with otherwise low and stable suicide rates until that time (such as Greece) or in countries with a robust increasing trend (such as Slovakia).

Third, an important and robust finding of the current study was the strong correlation of suicide rates with GDP per capita, although such an effect was not detected by the regression analysis. This correlation was of the magnitude of 0.80 and was found in the vast majority of countries with independent calculations. The correlation was strong within countries and weaker across countries (and also in the regression models) suggesting that the GDP is related to fluctuations in the suicide rates but may not be with the absolute baseline value. Unemployment was more important for countries outside the Eurozone area. This pattern is rather difficult to interpret.

The GDP was first developed in 1934 by Simon Kuznets ${ }^{43}$ and the danger of using it as a measure of welfare was pointed out by the author. It was established as the main tool to measure a country's economy in 1944 after the Bretton Woods conference. In spite of the early warnings, the GDP per capita is often used as a measurement of the standard of living. This is based on the assumption that all citizens would benefit from the economic growth of their country. However, essentially it is not such an 
Table 6 Correlation between suicide rates and economic variables across countries during the same year

$\begin{array}{lcccc} & \text { National } & \text { National } & \\ \text { Suicide } & \text { unemployment } & \text { growth } & \text { GDP } & \\ \text { rate } & \text { rate } & \text { rate } & \text { (per capita) } & \text { Inflation }\end{array}$

2000

\begin{tabular}{ccccr} 
Total & 0.28 & -0.04 & -0.32 & 0.03 \\
Men & 0.31 & -0.02 & -0.36 & 0.09 \\
Women & 0.17 & -0.04 & -0.22 & -0.12 \\
\hline 2001 & & & & \\
Total & 0.29 & 0.14 & -0.34 & -0.09 \\
Men & 0.37 & 0.20 & -0.43 & 0.00 \\
Women & 0.23 & 0.01 & -0.28 & -0.12 \\
\hline
\end{tabular}

$\begin{array}{ccccc}2002 & & & & \\ \text { Total } & 0.26 & 0.30 & -0.44 & -0.13 \\ \text { Men } & 0.29 & 0.32 & -0.46 & -0.13 \\ \text { Wh } & 0.10 & 0.12 & -0.25 & -0.21\end{array}$

$\begin{array}{lllll}\text { Men } & 0.29 & 0.32 & -0.46 & -0.13 \\ \text { Women } & 0.10 & 0.12 & -0.25 & -0.21\end{array}$

\begin{tabular}{lllll|}
2003 & & & & \\
$\quad$ Total & 0.24 & 0.24 & -0.39 & -0.20 \\
Men & 0.33 & 0.31 & -0.48 & -0.20 \\
Women & 0.13 & 0.03 & -0.22 & -0.26 \\
\hline
\end{tabular}

\begin{tabular}{|llllr|}
\hline 2004 & & & & \\
Total & 0.23 & 0.29 & -0.42 & 0.12 \\
Men & 0.29 & 0.41 & -0.51 & 0.26 \\
Women & 0.06 & 0.06 & -0.20 & -0.18 \\
\hline
\end{tabular}

\begin{tabular}{|ccccc|}
\hline 2005 & & & & -0.20 \\
Total & 0.25 & 0.28 & -0.38 & 0.08 \\
Men & 0.30 & 0.35 & -0.47 & 0.15 \\
Women & 0.12 & 0.02 & -0.17 & -0.15 \\
\hline
\end{tabular}

\begin{tabular}{|ccccr|}
\hline Men & 0.30 & 0.35 & -0.47 & 0.15 \\
Women & 0.12 & 0.02 & -0.17 & -0.15 \\
\hline 2006 & & & & \\
Total & 0.13 & 0.23 & -0.34 & -0.02 \\
Men & 0.21 & 0.31 & -0.45 & 0.07 \\
Women & 0.07 & -0.05 & -0.14 & -0.27 \\
\hline
\end{tabular}

\begin{tabular}{|lrrrr|}
\hline 2007 & & & & \\
Total & 0.00 & 0.19 & -0.33 & 0.37 \\
Men & 0.06 & 0.30 & -0.43 & 0.46 \\
Women & -0.01 & -0.03 & -0.15 & 0.11 \\
\hline 2008 & & & & \\
Total & 0.13 & 0.09 & -0.39 & 0.42 \\
Men & 0.20 & 0.14 & -0.46 & 0.45 \\
Women & 0.03 & -0.04 & -0.20 & 0.18 \\
\hline 2009 & & & & \\
Total & 0.35 & -0.36 & -0.30 & 0.00 \\
Men & 0.42 & -0.35 & -0.42 & 0.05 \\
Women & 0.17 & -0.27 & -0.13 & -0.03 \\
\hline 2010 & & & & \\
Total & 0.22 & -0.11 & -0.41 & -0.09 \\
Men & 0.34 & -0.04 & -0.49 & -0.08 \\
Women & -0.09 & -0.02 & 0.01 & 0.00 \\
\hline 2011 & & & & \\
Total & 0.50 & 0.32 & -0.46 & 0.13 \\
Men & 0.51 & 0.39 & -0.54 & 0.28 \\
Women & 0.41 & 0.18 & -0.20 & -0.10 \\
\hline
\end{tabular}

indicator and it is not a measure of personal income, since it does not take into consideration the inequalities within a given country. Nevertheless, a similar index, the gross national income (GNI) per capita is included as a significant contributor to the Human Development Index (HDI). ${ }^{44}$ In this paper, all the economic indices checked by the authors (Gini index, private debt \% of GDP, HDI) did not manifest any pattern that would relate them to the change in the suicide rates trends after 2007.

One previous study reported that cross-sectionally the GDP per capita had a tendency to correlate with suicide rates in males $(r=0.3, P=0.06)$ but not in females $(r=0.2, P=0.9) .{ }^{45}$ Our results are in accord with this. However, the relationship of GDP with suicidality seems to be more complex and it might follow an inverted U-shaped curve, with suicide trends declining after peaking at a certain threshold of economic development. ${ }^{46}$ At low GDP levels, increases in GDP are associated with increases in suicide rates, but once a given threshold of economic development is reached, further increases in GDP do not correlate with further increases in suicide rates. ${ }^{47}$

Overall, there was a worldwide increase in the purchasing power parity-adjusted GDP per capita over the past 3 decades, and during the same time period the suicide rates have increased in developing Latin American and Caribbean countries and in several high-income Asian countries (such as Japan and South Korea), and have decreased in the majority of European countries and Canada. ${ }^{48}$ Suicide rates in India were also positively correlated with GDP rates although the quality of the data is low and should be interpreted with caution. ${ }^{49-53}$ Concerning Japan and South Korea, they are both high-income countries with universal health coverage but with the private health sector prevailing over public health resources. In South Korea, although life expectancy has rapidly increased, mortality as a result of suicide increased, particularly among men aged 30 years or older. $^{54}$

It seems that economic growth is not invariably followed by a decrease in suicide rates, especially because income inequality causes them to increase. ${ }^{55}$ Also if economic growth is not accompanied by adequate infrastructures for mental health services, suicide rates might trend up. ${ }^{53}$

\section{Suicide rates and mental illness}

When studying the possible causes of suicide, one should have in mind that suicide is probably the end result of an interaction between many different risk factors with mental disorders being the decisive one. ${ }^{40,56}$ It is solidly proven that over $90 \%$ of people who die from suicide have a mental illness. Mood disorders are found in $80-85 \%^{40,42,57}$ and schizophrenia in $9-13 \%$ of people dying each year because of suicide. ${ }^{58}$ The significance of mental disorders may be much smaller in low- and middleincome countries. ${ }^{59}$ Other risk factors in the field of psychiatry also exist, including personality disorders and substance and alcohol dependence, ${ }^{60,61}$ and a family history of suicide. ${ }^{60,62,63}$ Ethnic group, ${ }^{64}$ problematic coping skills ${ }^{65}$ and environmental variables such as recent psychosocial stress ${ }^{66,67}$ and occupational problems or interpersonal problems with spouses or romantic partners ${ }^{68}$ also constitute risk factors. The availability and access to lethal means (such as firearms) might be of importance. ${ }^{42}$ Theoretically, any intervention that helps reducing these risk factors could ultimately reduce the suicide rate; however this has not been solidly proven for most of these variables. ${ }^{40}$ Unfortunately, research on suicide is limited by the fact that the majority of suicide victims die at the first attempt. ${ }^{69,70}$

The first to suggest that the suicide rate depends on socioeconomic driving forces was Enrico Agostino Morselli in 1882. ${ }^{71}$ Since then, suicide has usually been considered a social problem, and several risk factors have been related to suicidal behaviour, both at the subject level (microsocioeconomic factors) and at the state level (macrosocioeconomic level). ${ }^{56,72}$

\section{Suicide prevention}

An example of a successful programme aiming to reduce suicide rates is the National Service Framework target set in the UK in 1999, which aimed to reduce suicides by at least $20 \%$ by 2010. This target was achieved. The interventions included awareness campaigns and encouragement particularly to general 
practitioners to recognise depression and treat it early, especially with the use of selective serotonin reuptake inhibitors. However, in the USA and the Netherlands the official warning in 2003-4 was against prescribing selective serotonin reuptake inhibitors for young people, and this was followed by a reduction in prescribing and a detected increase in suicides in that age group. ${ }^{73}$ In Slovenia an increase in antidepressant use lead to a decrease in the suicide rate $^{74}$ and this seems to be true for Sweden, ${ }^{75,76}$ Hungary, ${ }^{77}$ Europe as a whole ${ }^{78}$ and all Organisation for Economic Co-operation and Development countries. ${ }^{79,80}$ It seems that in spite of potential problems, the use of antidepressants overall decreases suicide rates. ${ }^{81}$

Most of the risk factors are likely to be dependent on the victim's behaviour and thus do not constitute independent factors, ${ }^{82}$ however the recent economic crisis constitutes a stress factor that is independent of the behaviour of the person, although people with specific behaviours (such as great risk-taking entrepreneurs) are likely to be more vulnerable to the crisis. On the other hand, specific cultures (such as Hispanic people in the USA) seem to have some kind of protective effects against suicidal behaviour. $^{83}$ Additional support for this comes from the conclusion of a recent review that only the creation of social support networks reduces suicidality and that other interventions are of unproven effectiveness. ${ }^{84-87}$ Although it has been suggested that a reduction in unemployment through governmental action should lead to a reduction in suicidality, ${ }^{88}$ this remains an unproven theoretical suggestion, and is not supported by the results of the current study.

\section{Findings from other studies}

In his seminal work in 1979, Brenner reported that for every $10 \%$ increase in unemployment there is an increase of $1.2 \%$ in total mortality, including an increase by $1.7 \%$ in suicidality. ${ }^{89}$ Suicide rates are lower in Western high-income countries in comparison with low- and middle-income countries. ${ }^{90}$ The relationship of suicide rates with GDP suggests that suicide rates drop in times of economic expansion and increase in times of recession. ${ }^{91}$ It has been argued that business cycles affect suicide rates in the USA with the overall suicide rate usually rising during recessions and falling during expansions. ${ }^{25}$ In the past, economic crises have been correlated with increases in suicides, such as the Great depression, ${ }^{21,23,92,93}$ the Russian crisis in the early $1990 \mathrm{~s}^{33}$ (although the data are not published reliably) and the Asian economic crisis in the late 1990 s. $^{26,27}$ On the contrary, other authors suggested that actually recessions improve several health indicators. ${ }^{94-96}$ Concerning the present economic crisis, it has been calculated that close to 5000 excess suicides occurred in the year 2009, with the increase consisting mainly of men of working age and with unemployment a direct causal factor. ${ }^{33}$ A deterioration in mental health with increasing depression and anxiety rates has been reported after the economic crisis in Hong Kong, ${ }^{97}$ south Australia, ${ }^{98}$ Greece, ${ }^{99} \mathrm{UK}^{15}$ and Spain, ${ }^{30}$ and the effect seemed more severe in population groups who experienced unstable employment or financial problems. ${ }^{30,97,98}$ However, the methodology of these studies cannot differentiate between general distress and clinical mood disorders and thus any link of these results with the suicide rates is problematic.

\section{Variations between countries in suicide rates}

There are considerable variations in the effect of the crisis on the suicide rate across countries and it is unclear whether these variations relate to the severity of the recession as well as to varying social support and labour market protections in different countries, as it has been previously suggested. ${ }^{12,33,88}$ We were also unable to reproduce the finding that there are stronger associations between increases in national suicide rates and unemployment rates in countries with low baseline unemployment rates than in countries with high unemployment rates. ${ }^{33}$ On the contrary, we found that the baseline suicide rate was correlated with the overall pattern of the curve of suicide rates after the nadir year.

\section{Social capital}

One area that deserves further research is that of the so called 'social capital'. Overall, the results of the current study imply that there were profound changes within the society of all European countries that preceded the economic crisis, however they were probably related to it or they might even constitute part of its aetiopathogenesis. The 'social capital' theory refers to the importance for the community of building generalised trust and, at the same time, the importance of individual free choice, in order to create a more cohesive society. It could be defined as 'the aggregate of the actual or potential resources which are linked to possession of a durable network of more or less institutionalized relationships of mutual acquaintance and recognition.' ${ }^{100-102}$ A decline in social capital is considered to be at the core of modern socioeconomic problems. ${ }^{103-105}$ Social cohesion has already been recognised as a factor influencing the suicide rate. ${ }^{106}$

\section{Limitations}

The current study has a number of limitations. It is an observational analysis based on aggregate data collected from national statistical agencies. Probably there are differences between countries both in the quality of the data as well as in the level of misclassification of suicide, and these could lead to potential bias between countries, ${ }^{107}$ but it is not expected they had a significant impact on the results of the current study.

Cross-level bias and aggregation bias are typical of studies similar to the current one. ${ }^{108}$ The effects observed at the aggregate level might be modulated by the ecological context at the level of the individual. ${ }^{109}$ Also time series data are frequently non-stationary and vulnerable to random findings. ${ }^{109}$ Another source of bias is possible registration bias concerning suicides between countries and over time, and also concerning the quality of the economical statistics.

Finally, an important fundamental problem is that it is probably too early to arrive at conclusions concerning the impact of the current economic crisis on health, mental health and the suicide rate in particular. It seems necessary to wait until data up to at least 2020 are gathered in order to have a complete picture.

The authors chose to publish the full data-set their analysis was based on in an online table as they strongly believe that this database should be publicly available. One of the major obstacles of the current study was the difficulty of gathering statistical data from the various countries, although these data should had been easily accessible to every citizen. The authors believe that the publication of this data-set so that anyone can perform further analysis is one of the major contributions of the current study.

\section{Funding}

P.D. and X.G. are recipients of the Janos Bolyai Fellowship of the Hungarian Academy of Sciences. 
Konstantinos N. Fountoulakis, MD, Associate Professor of Psychiatry, 3rd Department of Psychiatry, School of Medicine, Aristotle University of Thessaloniki, Greece; Wolfram Kawohl, MD, Center for Social Psychiatry, Department of Psychiatry, Psychotherapy and Psychosomatics, Psychiatric Hospital, University of Zurich, Zurich, Switzerland; Pavlos N. Theodorakis, MD, Mental Health Hospitals Trust of Attica 'Dafni \& Dromokaiteio' and WHO National Counterpart for Mental Health, Athens, Greece; Ad J. F. M. Kerkhof, MD, Faculty of Psychology and Education, Department of Clinical Psychology, VU University Amsterdam, Amsterdam The Netherlands; Alvydas Navickas, MD, PhD, Associate Professor, Psychiatric Clinic, Vilnius University Medical Faculty, Vilnius, Lithuania; Cyril Höschl, MD, Prague Psychiatric Center/NIMH, Czech Republic; Dusica Lecic-Tosevski, MD, Professor of Psychiatry, Belgrade University School of Medicine and Institute of Mental Health, WHO Collaborating Centre, Belgrade, Serbia; Eliot Sorel, MD, The George Washington University, School of Medicine \& School of Public Health, Washington DC USA; Elmars Rancans, MD, PhD, Chair of the Department of Psychiatry and Narcology, Riga Stradins University, Latvia; Eva Palova, MD, Department of Psychiatry, University Hospital, Slovakia; Georg Juckel, MD, PhD, Department of Psychiatry, Ruhr University Bochum, LWL-University Hospital, Bochum, Germany; Goran Isacsson, MD, Associate Professor, Department of Clinical Neuroscience, Karolinska Institutet, Sweden; Helena Korosec Jagodic, Psychiatric Hospital Vojnik, Vojnik, Slovenia; Ileana Botezat-Antonescu, MD, Associate Professor, National Mental Health Center and Anti-drug, Bucharest, Romania; Ingeborg Warnke, PhD, Center for Social Psychiatry, Department of Psychiatry, Psychotherapy and Psychosomatics, Psychiatric Hospital, University of Zurich, Zurich, Switzerland; Janusz Rybakowski, Department of Adult Psychiatry, Poznan University of Medical Sciences, Poznan, Poland; Jean Michel Azorin, MD, Department of Psychiatry, Sainte Marguerite Hospital, Marseille, France; John Cookson, FRCP, FRCPsych, DPhil, East London NHS Trust, London, UK; John Waddington, PhD, DSC, Molecular \& Cellular Therapeutics, Royal College of Surgeons in Ireland, Dublin, Ireland; Pete Pregelj, University Psychiatric Hospital, Ljubljana, Slovenia; Koen Demyttenaere, University Psychiatric Center KU Leuven, Leuven, Belgium; Luchezar G. Hranov, MD, $\mathrm{PhD}$, Associate Professor, Second Psychiatric Clinic, University Hospital for Active Treatment in Neurology and Psychiatry 'Sveti Naum', Sofia, Bulgaria; Lidija Injac Stevovic, Associate Professor of Psychiatry, Psychiatric Clinic, Clinical Center of Montenegro, School of Medicine in Podgorica, University of Montenegro, Montenegro; Lucas Pezawas, MD, Associate Professor, Division of Biological Psychiatry, Department of Psychiatry and Psychotherapy, Medical University of Vienna, Vienna Austria; Marc Adida, MD, PhD, Department of Psychiatry, Sainte Marguerite Hospita Marseille, France; Maria Luisa Figuera, MD, Full Professor of Psychiatry and Menta Health, University Psychiatric Clinic and University of Lisbon, Lisbon, Portugal; Maurizio Pompili, MD, PhD, Department of Neurosciences, Mental Health and Sensory Organs, Suicide Prevention Center, Sant'Andrea Hospital, Sapienza University of Rome, Rome, Italy; Miro Jakovljević, Department of Psychiatry, University Hospital Center Zagreb, Croatia; Monica Vichi, MSc, Centre for Epidemiology, Surveillance and Health Promotion (CNESPS), National Institute of Health (ISS), Rome, Italy; Giulio Perugi, MD, Professor, Department of Clinical and Experimental Medicine, Psychiatry Unit, University of Pisa and Institute of Behavioral Sciences 'G. De Lisio', Pisa, Italy; Ole Andreassen, NORMENT, KG Jebsen Centre for Psychosis Research, Division of Mental Health and Addiction, Oslo University Hospital and Institute of Clinical Medicine, University of Oslo, Oslo, Norway; Olivera Vukovic School of Medicine, University of Belgrade, Institute of Mental Health, Belgrade, Serbia; Paraskevi Mavrogiorgou, MD, Department of Psychiatry, Ruhr University Bochum, LWL-University Hospital, Bochum, Germany; Peeter Varnik, EstonianSwedish Mental Health and Suicidology Institute, Tallinn, Estonia; Per Bech, Psychiatric Research Unit, Mental Health Centre North Zealand, University of Copenhagen, Hillerød, Denmark; Peter Dome, Department of Clinical and Theoretica Mental Health, Semmelweis University, Faculty of Medicine and National Institute of Psychiatry and Addictions, Laboratory for Suicide Research and Prevention, Budapest, Hungary; Petr Winkler, MD, Prague Psychiatric Center/NIMH, Czech Republic; Raimo K. R. Salokangas, MD, Professor of Psychiatry, Department of Psychiatry, University of Turku, Finland; Tiina From, Department of Psychiatry, University of Turku, Turku, Finland; Vita Danileviciute, MD, Professor and Head of the Vilnius University Medical Faculty Psychiatric Clinic, Vilnius, Lithuania; Xenia Gonda, PhD, Department of Clinical and Theoretical Mental Health, Semmelweis University, Budapest and Department of Pharmacodynamics, Semmelweis University, MTA-SE Neuropsychopharmacology and Neurochemistry Research Group, Hungarian Academy of Sciences, Semmelweis University, Budapest and National Institute of Psychiatry and Addictions, Laboratory for Suicide Research and Prevention, Budapest, Hungary; Zoltan Rihmer, MD, Department of Clinical and Theoretical Mental Health Semmelweis University, Faculty of Medicine and National Institute of Psychiatry and Addictions, Laboratory for Suicide Research and Prevention, Budapest, Hungary: Jonas Forsman Benhalima, Department of Clinical Neuroscience, Karolinska Institutet, Sweden; Anne Grady, Cert Business, Molecular \& Cellular Therapeutics, Royal College of Surgeons in Ireland, Dublin, Ireland; Anne Katrine Kloster Leadholm, NORMENT, KG Jebsen Centre for Psychosis Research, Division of Menta Health and Addiction and University Hospital \& Institute of Clinical Medicine, University of Oslo, Oslo, Norway; Susan Soendergaard, Psychiatric Research Unit, Mental Health Centre North Zealand, University of Copenhagen, Hillerød, Denmark; Carlos Nordt, PhD, Center for Social Psychiatry, Department of Psychiatry, Psychotherapy and Psychosomatics, Psychiatric Hospital, University of Zurich, Zurich, Switzerland; Juan Lopez-Ibor, MD, Emeritus Professor, Juan José López-Ibor Foundation and Department of Psychiatry and Clinical Psychology, School of Medicine, Universidad Complutense de Madrid, Spain

Correspondence: Konstantinos N. Fountoulakis, 3rd Department of Psychiatry, School of Medicine, Aristotle University of Thessaloniki, 6 Odysseos Street (1st Parodos, Ampelonon Street), 55535 Pournari Pylaia, Thessaloniki, Greece. Email: kfount@med.auth.gr

First received 25 Feb 2014, final revision 17 Jun 2014, accepted 27 Jun 2014

\section{References}

1 International Labour Organization. ILO Global Employment Trends 2010Unemployment reaches Highest Level on Record in 2009. ILO, 2010 (http:// www.ilo.org/manila/info/public/pr/WCMS_124768/lang-en/index.htm).

2 Reeves A, McKee M, Basu S, Stuckler D. The political economy of austerity and healthcare: cross-national analysis of expenditure changes in 27 European nations 1995-2011. Health Policy 2014; 115: 1-8.

3 Reeves A, Basu S, McKee M, Marmot M, Stuckler D. Austere or not? UK coalition government budgets and health inequalities. J R Soc Med 2013; 106: $432-6$.

4 Mckee M, Balabanova D, Basu S, Ricciardi W, Stuckler D. Universal health coverage: a quest for all countries but under threat in some. Value Health 2013; 16 (suppl 1): S39-45

5 Karanikolos M, Mladovsky P, Cylus J, Thomson S, Basu S, Stuckler D, et al. Financial crisis, austerity, and health in Europe. Lancet 2013; 381: 1323-31.

6 Suhrcke M, Stuckler D. Will the recession be bad for our health? It depends. Soc Sci Med 2012; 74: 647-53.

7 Kentikelenis A, Karanikolos M, Papanicolas I, Basu S, McKee M, Stuckler D. Effects of Greek economic crisis on health are real. BMJ 2012; 345: e8602.

8 Stuckler D, Basu S, Suhrcke M, Coutts A, McKee M. Effects of the 2008 recession on health: a first look at European data. Lancet 2011; 378: 124-5.

9 Mckee M, Stuckler D. The assault on universalism: how to destroy the welfare state. BMJ 2011; 343: d7973.

10 Kentikelenis A, Karanikolos M, Papanicolas I, Basu S, McKee M, Stuckler D. Health effects of financial crisis: omens of a Greek tragedy. Lancet 2011; 378: $1457-8$.

11 Stuckler D, Basu S, McKee M, Suhrcke M. Responding to the economic crisis: a primer for public health professionals. J Public Health 2010; 32: 298-306.

12 Stuckler D, Basu S, McKee M. Budget crises, health, and social welfare programmes. BMJ 2010; 340: C3311.

13 Biggs B, King L, Basu S, Stuckler D. Is wealthier always healthier? The impact of national income level, inequality, and poverty on public health in Latin America. Soc Sci Med 2010; 71: 266-73.

14 Stuckler D, Basu S, Suhrcke M, McKee M. The health implications of financial crisis: a review of the evidence. Ulster Med J 2009; 78: 142-5.

15 Katikireddi SV, Niedzwiedz CL, Popham F. Trends in population mental health before and after the 2008 recession: a repeat cross-sectional analysis of the 1991-2010 Health Surveys of England. BMJ Open 2012; 2: 5 .

16 World Health Organization. Financial Crisis and Global Health: Report of a High-Level Consultation. WHO, 2009 (http://www.who.int/topics/ financial_crisis/financialcrisis_report_200902.pdf)

17 Smith $\mathrm{H}$. WHO apologises for claiming half of Greek HIV infections are selfinflicted. Guardian 2013, 26 November (http://www.theguardian.com/world/ 2013/nov/26/who-apologises-hiv-infections-greece-self-inflicted).

18 World Health Organization. Review of Social Determinants and the Health Divide in the WHO European Region: Final Report. WHO, 2014. Available from: (http://www.euro.who.int/_data/assets/pdf_file/0004/251878/Review-ofsocial-determinants-and-the-health-divide-in-the-WHO-European-RegionFINAL-REPORT.pdf?ua = 1).

19 Fountoulakis KN, Grammatikopoulos IA, Koupidis SA, Siamouli M, Theodorakis PN. Health and the financial crisis in Greece. Lancet 2012; 379: 1001-2.

20 Fountoulakis KN, Savopoulos C, Siamouli M, Zaggelidou E, Mageiria S, lacovides A, et al. Trends in suicidality amid the economic crisis in Greece. Eur Arch Psychiatry Clin Neurosci 2013; 263: 441-4.

21 Swinscow D. Some suicide statistics. BMJ 1951; 1: 1417-23.

22 Milner A, Page A, LaMontagne AD. Duration of unemployment and suicide in Australia over the period 1985-2006: an ecological investigation by sex and age during rising versus declining national unemployment rates. J Epidemiol Community Health 2013; 67: 237-44.

23 Morrell S, Taylor R, Quine S, Kerr C. Suicide and unemployment in Australia 1907-1990. Soc Sci Med 1993; 36: 749-56.

24 Lester D, Yang B. The relationship between divorce, unemployment and female participation in the labour force and suicide rates in Australia and America. Aust N Z J Psychiatry 1991; 25: 519-23.

25 Luo F, Florence CS, Quispe-Agnoli M, Ouyang L, Crosby AE. Impact of business cycles on US suicide rates, 1928-2007. Am J Public Health 2011; 101: 1139-46.

26 Chang SS, Gunnell D, Sterne JA, Lu TH, Cheng AT. Was the economic crisis 1997-1998 responsible for rising suicide rates in East/Southeast Asia? A time-trend analysis for Japan, Hong Kong, South Korea, Taiwan Singapore and Thailand. Soc Sci Med 2009; 68: 1322-31. 
27 Chang SS, Sterne JA, Huang WC, Chuang HL, Gunnell D. Association of secular trends in unemployment with suicide in Taiwan, 1959-2007: a time-series analysis. Public Health 2010; 124: 49-54.

28 Anonymous. Sharp rise in suicides amid crisis. ekathimerini.com 2011; 30 June (http://www.ekathimerini.com/4dcgi/_w_articles_wsite1_1_30/06/ 2011_396649).

29 Economou M, Madianos M, Theleritis C, Peppou LE, Stefanis CN. Increased suicidality amid economic crisis in Greece. Lancet 2011; 378: 1459.

30 Gili M, Roca M, Basu S, McKee M, Stuckler D. The mental health risks of economic crisis in Spain: evidence from primary care centres, 2006 and 2010. Eur J Public Health 2013; 23: 103-8.

31 De Vogli R, Marmot M, Stuckler D. Excess suicides and attempted suicides in Italy attributable to the great recession. J Epidemiol Community Health 2013; 67: $378-9$.

32 De Vogli R, Marmot M, Stuckler D. Strong evidence that the economic crisis caused a rise in suicides in Europe: the need for social protection. J Epidemiol Community Health 2013; 67: 298.

33 Chang SS, Stuckler D, Yip P, Gunnell D. Impact of 2008 global economic crisis on suicide: time trend study in 54 countries. BMJ 2013; 347: f5239.

34 Reeves A, Stuckler D, McKee M, Gunnell D, Chang SS, Basu S. Increase in state suicide rates in the USA during economic recession. Lancet 2012; $\mathbf{3 8 0}$ 1813-4

35 Barr B, Taylor-Robinson D, Scott-Samuel A, McKee M, Stuckler D. Suicides associated with the 2008-10 economic recession in England: time trend analysis. BMJ 2012; 345: e5142.

36 Fountoulakis KN, Koupidis SA, Grammatikopoulos IA, Theodorakis PN. First reliable data suggest a possible increase in suicides in Greece. $B M J$ 2013; 347: f4900.

37 Economou M, Madianos M, Peppou LE, Theleritis C, Patelakis A, Stefanis C. Suicidal ideation and reported suicide attempts in Greece during the economic crisis. World Psychiatry 2013; 12: 53-9.

38 Fountoulakis KN, Siamouli M, Grammatikopoulos IA, Koupidis SA, Siapera M, Theodorakis PN. Economic crisis-related increased suicidality in Greece and Italy: a premature overinterpretation. J Epidemiol Community Health 2013; 67: $379-80$.

39 Fountoulakis KN, Koupidis SA, Siamouli M, Grammatikopoulos IA, Theodorakis PN. Suicide, recession, and unemployment. Lancet 2013; 381: 721-2.

40 Mann JJ, Apter A, Bertolote J, Beautrais A, Currier D, Haas A, et al. Suicide prevention strategies: a systematic review. JAMA 2005; 294 2064-74.

41 Tondo L, Albert MJ, Baldessarini RJ. Suicide rates in relation to health care access in the United States: an ecological study. J Clin Psychiatry 2006; 67 $517-23$

42 Rihmer Z, Kantor Z, Rihmer A, Seregi K. Suicide prevention strategies a brief review. Neuropsychopharmacol Hung 2004; 6: 195-9.

43 Kuznets S. National income, 1929-1932. National Bureau of Economic Research Bull 1934; 49: 7 June (http://www.nber.org/chapters/c2258.pdf)

44 United Nations. Human Developing Reports. UN, 2014 (http://hdr.undp.org/ en).

45 Sher L. Per capita income is related to suicide rates in men but not in women. J Mens Health Gend 2006; 3: 39-42.

46 Moniruzzaman S, Andersson R. Economic development as a determinant of injury mortality - a longitudinal approach. Soc Sci Med 2008; 66: 1699-708.

47 Voracek M. Suicide rates, national intelligence estimates, and differential $\mathrm{K}$ theory. Percept Mot Skills 2009; 109: 733-6.

48 Blasco-Fontecilla $\mathrm{H}$, Perez-Rodriguez MM, Garcia-Nieto R, Fernandez-Navarro $\mathrm{P}$, Galfalvy $\mathrm{H}$, de Leon J, et al. Worldwide impact of economic cycles on suicide trends over 3 decades: differences according to level of development. A mixed effect model study. BM Open 2012; 2: 3

49 Soman CR, Safraj S, Kutty VR, Vijayakumar K, Ajayan K. Suicide in South India: a community-based study in Kerala. Indian J Psychiatry 2009; 51: $261-4$.

50 Gajalakshmi V, Peto R. Suicide rates in rural Tamil Nadu, South India: verbal autopsy of 39000 deaths in 1997-98. Int J Epidemiol 2007; 36: 203-7.

51 Prasad J, Abraham VJ, Minz S, Abraham S, Joseph A, Muliyil JP, et al. Rates and factors associated with suicide in Kaniyambadi Block, Tamil Nadu, South India, 2000-2002. Int J Soc Psychiatry 2006; 52: 65-71.

52 Abraham VJ, Abraham S, Jacob KS. Suicide in the elderly in Kaniyambad block, Tamil Nadu, South India. Int J Geriatr Psychiatry 2005; 20: 953-5.

53 Jacob KS, Sharan P, Mirza I, Garrido-Cumbrera M, Seedat S, Mari JJ, et al. Mental health systems in countries: where are we now? Lancet 2007; 370 1061-77.
54 Yang S, Khang YH, Harper S, Davey Smith G, Leon DA, Lynch J. Understanding the rapid increase in life expectancy in South Korea. Am J Public Health 2010; 100: 896-903.

55 Chen J, Choi Y, Sawada YH. How is suicide different in Japan? Japan World Econ 2009; 21: 140-50.

56 Qin $\mathrm{P}$, Agerbo E, Mortensen PB. Suicide risk in relation to socioeconomic, demographic, psychiatric, and familial factors: a national register-based study of all suicides in Denmark, 1981-1997. Am J Psychiatry 2003; 160 : 765-72.

57 Gray SM, Otto MW. Psychosocial approaches to suicide prevention: applications to patients with bipolar disorder. J Clin Psychiatry 2001; 62 (suppl 25): 56-64.

58 Meltzer HY. Suicide and schizophrenia: clozapine and the InterSePT study. International Clozaril/Leponex Suicide Prevention Trial. J Clin Psychiatry 1999; 60 (suppl 12): 47-50.

59 Manoranjitham SD, Rajkumar AP, Thangadurai P, Prasad J, Jayakaran R, Jacob KS. Risk factors for suicide in rural south India. Br J Psychiatry 2010; 196: 26-30.

60 Oquendo MA, Bongiovi-Garcia ME, Galfalvy H, Goldberg PH, Grunebaum MF, Burke AK, et al. Sex differences in clinical predictors of suicidal acts after major depression: a prospective study. Am J Psychiatry 2007; 164: 134-41.

61 Comtois KA, Russo JE, Roy-Byrne P, Ries RK. Clinicians' assessments of bipolar disorder and substance abuse as predictors of suicidal behavior in acutely hospitalized psychiatric inpatients. Biol Psychiatry 2004; 56: 757-63.

62 Cavazzoni P, Grof P, Duffy A, Grof E, Muller-Oerlinghausen B, Berghofer A, et al. Heterogeneity of the risk of suicidal behavior in bipolar-spectrum disorders. Bipolar Disord 2007; 9: 377-85.

63 Hawton K, Sutton L, Haw C, Sinclair J, Harriss L. Suicide and attempted suicide in bipolar disorder: a systematic review of risk factors. J Clin Psychiatry 2005; 66: 693-704.

64 Kupfer DJ, Frank E, Grochocinski VJ, Houck PR, Brown C. African-American participants in a bipolar disorder registry: clinical and treatment characteristics. Bipolar Disord 2005; 7: 82-8.

65 Johnson MR, Lydiard RB, Morton WA, Laird LK, Steele TE, Kellner $\mathrm{CH}$, et al. Effect of fluvoxamine, imipramine and placebo on catecholamine function in depressed outpatients. J Psychiatr Res 1993; 27: 161-72.

66 Leverich GS, Altshuler LL, Frye MA, Suppes T, Keck PE Jr, McElroy SL, et al. Factors associated with suicide attempts in 648 patients with bipolar disorder in the Stanley Foundation Bipolar Network. J Clin Psychiatry 2003; 64: $506-15$

67 Leverich GS, McElroy SL, Suppes T, Keck PE Jr, Denicoff KD, Nolen WA, et al. Early physical and sexual abuse associated with an adverse course of bipolar illness. Biol Psychiatry 2002; 51: 288-97.

68 Tsai SY, Lee JC, Chen CC. Characteristics and psychosocial problems of patients with bipolar disorder at high risk for suicide attempt. J Affect Disord 1999; 52: 145-52.

69 Rihmer Z, Belso N, Kiss K. Strategies for suicide prevention. Curr Opin Psychiatry 2002; 15: 83-7.

70 Isometsa $\mathrm{E}$, Henriksson $\mathrm{M}$, Aro $\mathrm{H}$, Heikkinen $\mathrm{M}$, Kuoppasalmi $\mathrm{K}$, Lonnqvist J. Suicide in psychotic major depression. J Affect Disord 1994; 31: 187-91.

71 Morselli E. Suicide: Essay on Comparative Moral Statistics. Appleton \& Co, 1882.

72 Lester D, Yang BJ. Microsocionomics versus macrosocionomics as a model for examining suicide. Psychol Rep 1991; 69: 735-8.

73 Gibbons RD, Brown CH, Hur K, Marcus SM, Bhaumik DK, Erkens JA, et al. Early evidence on the effects of regulators' suicidality warnings on SSRI prescriptions and suicide in children and adolescents. Am J Psychiatry 2007; 164: $1356-63$

74 Korosec Jagodic $\mathrm{H}$, Rokavec T, Agius M, Pregelj P. Availability of mental health service providers and suicide rates in Slovenia: a nationwide ecological study. Croat Med J 2013; 54: 444-52.

75 Isacsson G, Holmgren A, Osby $U$, AhIner J. Decrease in suicide among the individuals treated with antidepressants: a controlled study of antidepressants in suicide, Sweden 1995-2005. Acta Psychiatr Scand 2009; 120: $37-44$.

76 Isacsson G, Ahlner J. Antidepressants and the risk of suicide in young persons - prescription trends and toxicological analyses. Acta Psychiatr Scand 2014; 129: 296-302.

77 Dome P, Kapitany B, Ignits G, Porkolab L, Rihmer Z. Tobacco consumption and antidepressant use are associated with the rate of completed suicide in Hungary: an ecological study. J Psychiatr Res 2011; 45: 488-94.

78 Gusmao R, Quintao S, McDaid D, Arensman E, Van Audenhove C, Coffey C, et al. Antidepressant utilization and suicide in europe: an ecological multi-national study. PLOS One 2013; 8: e66455. 
79 Kamat MA, Edgar L, Niblock P, McDowell C, Kelly CB. Association between antidepressant prescribing and suicide rates in oecd countries: an ecological study. Pharmacopsychiatry 2014; 47: 18-21.

80 Ludwig J, Marcotte DE, Norberg K. Anti-depressants and suicide. $J$ Health Econ 2009; 28: 659-76.

81 Ludwig J, Marcotte DE. Anti-depressants, suicide, and drug regulation. J Policy Anal Manage 2005; 24: 249-72.

82 Isometsa $\mathrm{E}$, Heikkinen $\mathrm{M}$, Henriksson $\mathrm{M}$, Aro $\mathrm{H}$, Lonnqvist J. Recent life events and completed suicide in bipolar affective disorder. A comparison with major depressive suicides. J Affect Disord 1995; 33: 99-106.

83 Oquendo MA, Dragatsi D, Harkavy-Friedman J, Dervic K, Currier D, Burke AK, et al. Protective factors against suicidal behavior in Latinos. J Nerv Ment Dis 2005; 193: 438-43.

84 Fountoulakis KN, Gonda X, Rihmer Z. Suicide prevention programs through community intervention. J Affect Disord 2011; 130: 10-6.

85 Rihmer Z, Gonda X, Fountoulakis KN. Suicide prevention programs through education in the frame of healthcare. Psychiatr Hung 2009; 24: 382-7.

86 Fountoulakis KN, Gonda X, Siamouli M, Rihmer Z. Psychotherapeutic intervention and suicide risk reduction in bipolar disorder: a review of the evidence. J Affect Disord 2009; 113: 21-9.

87 Gonda X, Fountoulakis KN, Kaprinis G, Rihmer Z. Prediction and prevention of suicide in patients with unipolar depression and anxiety. Ann Gen Psychiatry 2007; 6: 23 .

88 Stuckler D, Basu S, Suhrcke M, Coutts A, McKee M. The public health effect of economic crises and alternative policy responses in Europe: an empirical analysis. Lancet 2009; 374: 315-23.

89 Brenner M. Influence of the social environment on psychology: the historical perspective. In Stress and Mental Disorder (ed JE Barrett). Raven Press, 1979.

90 Jacob KS. The prevention of suicide in India and the developing world: the need for population-based strategies. Crisis 2008; 29: 102-6.

91 Tapia Granados JA. Increasing mortality during the expansions of the US economy, 1900-1996. Int J Epidemiol 2005; 34: 1194-202.

92 Stuckler D, Meissner C, Fishback P, Basu S, McKee M. Was the Great Depression a cause or correlate of significant mortality declines? An epidemiological response to Granados. J Epidemiol Community Health 2013; 67: 467.

93 Tapia Granados JA, Diez Roux AV. Life and death during the Great Depression. Proc Natl Acad Sci U S A 2009; 106: 17290-5.

94 Why are recessions good for your health? Natl Bur Econ Res Bull Aging Health 2012; 1: 1-2.
95 Ariizumi H, Schirle T. Are recessions really good for your health? Evidence from Canada. Soc Sci Med 2012; 74: 1224-31.

96 Ruhm CJ. Economic conditions and health behaviors: are recessions good for your health? N C Med J 2009; 70: 328-9.

97 Lee S, Guo WJ, Tsang A, Mak AD, Wu J, Ng KL, et al. Evidence for the 2008 economic crisis exacerbating depression in Hong Kong. J Affect Disord 2010; 126: 125-33.

98 Shi Z, Taylor AW, Goldney R, Winefield H, Gill TK, Tuckerman J, et al. The use of a surveillance system to measure changes in mental health in Australian adults during the global financial crisis. Int J Public Health 2011; 56: 367-72.

99 Economou M, Madianos M, Peppou LE, Patelakis A, Stefanis CN. Major depression in the era of economic crisis: a replication of a cross-sectional study across Greece. J Affect Disord 2013; 145: 308-14.

100 Portes A. Social capital: its origins and applications in modern sociology. Ann Rev Socio 1998; 24: 1-24.

101 Bourdieu P. The forms of capital. In Handbook of Theory and Research for the Sociology of Education (ed J Richardson): 241-58. Greenwood, 1986.

102 Ferragina E. Social Capital in Europe: A Comparative Regional Analysis. Edward Elgar Publishing, 2012.

103 Jain SH, Goyal R, Fox S, Shrank WH. Bowling alone, healing together: the role of social capital in delivery reform. Am J Manag Care 2012; 18 e209-11.

104 Evans $\mathrm{CH}$. Bowling alone: implications for academic medicine. Acad Med 1997; 72: $163-5$

105 Putnam R. Bowling alone: America's declining social capital. J Democracy 1995; 6: 65-78

106 Balint L, Dome P, Daroczi G, Gonda X, Rihmer Z. Investigation of the marked and long-standing spatial inhomogeneity of the Hungarian suicide rate: a spatial regression approach. J Affect Disord 2014; 155: 180-5.

107 Kapusta ND, Tran US, Rockett IR, De Leo D, Naylor CP, Niederkrotenthaler T, et al. Declining autopsy rates and suicide misclassification: a cross-national analysis of 35 countries. Arch Gen Psychiatry 2011; 68: 1050-7.

108 Moniruzzaman S, Andersson R. Relationship between economic development and suicide mortality: a global cross-sectional analysis in an epidemiological transition perspective. Public Health 2004; 118: 346-8.

109 Lucey S, Corcoran P, Keeley HS, Brophy J, Arensman E, Perry IJ. Socioeconomic change and suicide: a time-series study from the Republic of Ireland. Crisis 2005; 26: 90-4.

\title{
Addiction: biological aspects
}

\author{
David Nutt
}

Addiction, like cancer, is a strong word for a serious medical disorder. The experience of addiction is one of extreme drives that are resisted and recurrent episodes of despair as these drives overcome the best intentions of the patient. Stopping addictive behaviour leads to a period of withdrawal with at the least marked dysphoria and at the worst death. Almost everyone uses alcohol, tobacco or other drugs at some life stage, yet only a minority become addicted, proving specific individual vulnerabilities. These include significant genetic variables such as liver enzyme polymorphisms and brain processes such as dopamine and GABA dysfunction. 